\title{
BIO-ECONOMICAL STUDY OF CORONAVIRUS DISEASE AND THEIR IMPACT ON HUMAN BEING AND ECONOMY OF WORLD AND INDIA
}

\author{
Dr. JAGDISH CHANDRA ${ }^{1} \&$ Dr. PUSHPANJALI ARYA ${ }^{2}$ \\ ${ }^{1}$ Department of Botany, R.S.R Government Degree College, Barkot, Uttarkashi, Uttarakhand, India \\ ${ }^{2}$ Department of Economics, R.S.R Government Degree College, Barkot, Uttarkashi, Uttarakhand, India
}

\begin{abstract}
The novel corona virus (COVID-19) originated in Wuhan (China) and has spread rapidly across the globe. The $2019-20$ coronavirus outbreak, caused by COVID-19, was declared a pandemic by the World Health Organization (WHO) on 11 March 2020. We conducted a mutual study of the impact of coronavirus on diverse sectors such as human life and economy as well as data from the world, the most affected seven countries and India's total infected persons and dead persons till on 20 April 2020. We selected world data, seven countries who high affected and India for study for research work. The total data of seven most affected countries in the world and the world has been taken for adjective of various covid-19 data in various parts of India. There are daily release reports submitted by WHO for corona virus infection data has been on the based. WHO published its first report on $21^{\text {st }}$ January 2020, which included data dated on January 20 , 2020. After 13 weeks of the world, corona infections spread to a total of 212 countries and territories, with a total number of infected person reaching 2314621 and the total deaths reached 157847 more, respectively.

KEYWORDS: Coronavirus, Human life,Pandemic, Infection, Economy\& WHO
\end{abstract}

Received: May 01, 2020; Accepted: May 22, 2020; Published: Jun 04, 2020; Paper Id.: IJBRDJUN20203

\section{INTRODUCTION}

The novel coronavirus, COVID-19, originated inWuhan and has spread rapidly across the globe. The World Health Organization has declared it to be a pandemic.In the absence of a vaccine, social distancing hasemerged as the most widely adopted strategy for its mitigation and control ${ }^{1}$. Corona virusesare a group of related viruses that cause diseases in mammals and birds. In humans, corona viruses cause respiratory tract infections that can range from mild to lethal. Mild illnesses include some cases of the common cold (which has other possible causes, predominantly rhinoviruses), while more lethal varieties can cause SARS, MERS, and COVID-19. Symptoms in other species vary in chickens, they cause an upper respiratory tract disease, while in cows and pigs they cause diarrhea. There are yet to be vaccines or antiviral drugs to prevent or treat human corona virus infections. Illustration of the morphology of corona viruses, the club-shaped viral spike peplomers, colored red, create the look of a Corona surrounding the virion when observed with an electron microscope ${ }^{2}$. Corona virus disease 2019 (COVID-19) is an infectious disease caused by severe acute respiratory syndrome corona virus 2 (SARS-CoV-2) The disease was first identified in December 2019 in Wuhan, the capital of China's Hubei province, and has since spread globally, resulting in the ongoing 2019-20 corona virus pandemic ${ }^{4,5}$. The 2019-20 coronavirus outbreak, caused by COVID-19, was declared a pandemic by the World Health Organization (WHO) on 11 March $2020^{6}$. Local transmission of the disease has been recorded in many countries across all six WHO regions ${ }^{7}$. The first case of the 2019-20 coronavirus pandemic in India was reported on 30 January 2020, originating from China ${ }^{8}$. Corona virus infection, which started spreading from China, has so far spread to 212 countries in the world. So far, 2314621 
persons have been infected and 157847 persons have died till on 20 April 2020 all over the world. All countries are engaged in relief and rescue operations except for important work.The World Health Organization (WHO) declared the 2019-20 coronavirus outbreak a Public Health Emergency of International Concern (PHEIC) ${ }^{5,9}$ on 30 January 2020 and a pandemic on 11 March $2020^{10}$ In order to prevent the spread of corona virus, it is mandatory to keep the transport of public works, factories, schools, colleges, places of worship, so that the problem can be protected by the public community and the same is being carried out in most of the countries. In this research paper, we conducted a mutual study of the impact of coronavirus on diverse sectors such as human life and economy as well as data from the world, the most affected seven countries and India's total infected persons and dead persons till on 20 April 2020.

\section{MATERIAL AND METHODS}

We selected world data, seven countries that are highly affected and India for the study. The total data of seven most affected countries in the world and the world has been taken for adjective of various covid-19 data in various parts of India. For research, the collections were various information and data on human life and economy. In India, data has been collected through various journals, newspapers and internet, while data on the number of persons infected with covid-19, number of newly infected persons killed in the world was based on the report published daily by World Health Organization (WHO). The world report of WHO was published $20^{\text {th }}$ January 2020, which publishes data from coronaaffected countries of the world up to $20^{\text {th }}$ January 2020, hence a total of 13 weeks have been collected from $20^{\text {th }}$ January till $20^{\text {th }}$ April 2020 based on weekly data. A total of 91 days of data was collected by $20^{\text {th }}$ April on the basis of the data released by World Health Organization (WHO) for India, which was started to be published in the daily report from $2^{\text {nd }}$ March, along with necessary guidelines and information and data of the government of India, and State Governments of India. A research paper of inflammatory has been prepared by analyzing the total data of the world and data of world's five corona virus countries and the corona virus data of India.

\section{RESULTS}

1. Position and Symptoms of Coronavirus: The classification Corona virus asGroup IV ((+)SSRNA), Unranked-Virus, Realm-Riboviria, Phylum-incertaesedis, Order- Nidovirales Family-Coronaviridae, Subfamily-Orthocoronavirinae ${ }^{2}$. The following viruses could initially be referred to as "novel coronavirus", before being formally named, all four viruses are part of the Betacoronavirus genus within the coronavirus family ${ }^{11}$. ${ }^{12}$.Coronaviruses were first discovered in the 1930s when an acute respiratory infection of domesticated chickens was shown to be caused by infectious bronchitis virus $(\text { IBV })^{13}$. Human coronaviruses were discovered in the $1960 \mathrm{~s}^{14}$. The earliest ones studied were from human patients with the common cold, which were later named human coronavirus $229 \mathrm{E}$ and human coronavirus $\mathrm{OC} 43^{15}$. They were first imaged by Scottish virologist June Almeida at St. Thomas Hospital in London. The name "coronavirus" is derived from Latin corona, meaning "crown" or "wreath", itself a borrowing from Greek Kopwvn korone, "garland, wreath"16. The name was first used in 1968 by an informal group of virologists in the journal Nature to designate the new Coronaviruses are large pleomorphic spherical particles with bulbous surface projections ${ }^{17}$. They are enveloped viruses with a positive-sense singlestranded RNA genome and a nucleocapsid of helical symmetry. The genome size of coronaviruses ranges from approximately 26 to 32 kilo bases, one of the largest among RNA viruses ${ }^{18}$. The average diameter of the virus particles is around $120 \mathrm{~nm}(0.12 \mu \mathrm{m})$. The diameter of the envelope is $\sim 80 \mathrm{~nm}(0.08 \mu \mathrm{m})$ and the spikes are $\sim 20 \mathrm{~nm}(0.02 \mu \mathrm{m})$ long. The envelope of the virus in electron micrographs appears as a distinct pair of electron dense shells ${ }^{19,20}$. Novel coronavirus $(\mathrm{nCoV})$ is a provisional name given to coronaviruses of medical significance before a permanent name is decided upon. 
Although coronaviruses are endemic in humans and infections normally mild, such as the common cold (caused by human coronaviruses in $15 \%$ of cases), cross-species transmission has produced some unusually virulent strains, which can cause viral pneumonia and in serious cases even acute respiratory distress syndrome and death ${ }^{21}$. They have characteristic clubshaped spikes that project from their surface, which in electron micrographs create an image reminiscent of the solar corona from which their name derives ${ }^{22}$.The virus is primarily spread between people during close contact, often via small droplets produced by coughing, sneezing, or talking ${ }^{23,24}$. While these droplets are produced when breathing out, they usually fall to the ground or onto surfaces rather than being infectious over long distances ${ }^{23,25}$, People may also become infected by touching a contaminated surface and then touching their eyes, nose, or mouth ${ }^{26}$. The virus can survive on surfaces for up to 72 hours $^{27}$. It is most contagious during the first three days after the onset of symptoms, although spread may be possible before symptoms appear and in later stages of the disease ${ }^{28}$. The standard method of diagnosis is by realtime reverse transcription polymerase chain reaction (rRT-PCR) from a nasopharyngeal swab ${ }^{29}$. Chest CT imaging may also be helpful for diagnosis in individuals where there is a high suspicion of infection based on symptoms and risk factors; however, it is not recommended for routine screening ${ }^{30,31}$. Management involves treatment of symptoms, supportive care, isolation, and experimental measures ${ }^{31}$. In those who develop severe symptoms, time from symptom onset to needing mechanical ventilation is typically eight days ${ }^{32}$. The incubation period for COVID-19 is typically five to six days but may range from two to 14 days $^{33}, 97.5 \%$ of people who develop symptoms will do so within 11.5 days of infection ${ }^{34}$.

2. Impact on Human Being of Coronavirus: Corona virus infection has adversely affected the education, transportation, tourism, factories, health services, national budget, stock market, shopkeepers of students from all over the world. The people who are doing daily wages, irrespective of their kind of work, have seen the greatest impact. The impact on human life due to the lockdown of the corona virus infection can be seen on the world and India for a very long time. Theuncertainty, fear of infection and lack of social interaction all can be perceived by our bodies to fight-or-flight mode. A recent meta-analysis published in Neuroscience and Biobehavioral Reviews revealed that people who are more socially isolated have higher levels of C-reactive protein (CRP) and fibrinogen (a soluble protein that helps blood to clot), both of which are associated with chronic inflammation and poor physical and mental health. Another of-cited study in Perspectives on Psychological Science Indicated that lack of social connection and living alone can be detrimental to a person's health, respectively increasing mortality risk by 295 and 32\%. They also pointed out that social isolation can lead to several chronic conditions like hypertension, increased heart ${ }^{35}$. According to the survey report, covid-19 is having a deep impact on Indian business, over the coming months jobs are at high risk because forms are looking for some reduction in manpower. Further, it is added that already covid-19 pandemic has caused an unprecedented collapse is economic activities over the last few weeks ${ }^{36}$ as per tallest survey report of Centre for Monitoring Indian Economy (CMIE) survey, labourparticipation rate fell to 39\% in April. CMIE's estimates that unemployment rate shot up from 8.4\% in mid-March to $23.8 \%$ post lockdown. Thus, pushing 14 crore (1.4 million) people to lose employment during lockdown.

3. Impact of Covid-19 pandemic on India Economy: The world Economic outlook (WHO) of October 2019 has estimated India's economy to be the world's fifth largest economy, as measured using GDP at currentus \$ prices. The size of the Indian economy is estimated at US \$ 2.9 trillion in 2019. As per National statistical organization (NSO) estimates, India's GDP hasgrown at 4.8\% in the first half (April, Sept) of 2019-2020, lower than 6.2\% recorded in the second half (Oct, March) of 2018-2019. India's real GDP was the lowest to its in the last six years ${ }^{37}$, but the outbreak of covid-19 pandemic in Indian poised fresh challenges for the Indian economy. Today, the economy is fighting on two fronts- The growth front and the covid-19 pandemic control front, both being the heavy and tough fronts for the economy. The covid- 
19 pandemic has far reaching impacts on the economy. The impacts of covid-19 pandemic can be well seen as under:

3.1. On Growth of Indian Economy: According to the confederation of Indian Industry, the Indian economy is expected to slow down considerably with its estimates ranging from a contraction of $0.9 \%$ to growth of $1.5 \%$ in the current financial year due to covid-19 pandemic outbreak, and the subsequent lockdown. The extent of damages to the economy ranges from disruption to business to GDP growth in financial year 2021 will likely to be lowered. The economic costs of the lockdown are rising with each passing day and with the impact can be felt across all the sector of the economy ${ }^{38}$. The steps taken by the government of India to contain the spread of covid-19 pandemic and to limit the pandemic from community spread include, the complete Inter-Nation lockdown, and National lockdown, closures of hotels, malls, restaurants, transportation, has brought the Indian economy to a standstill. The economic activities with other countries and within the country come to a complete halt.

3.1.1. Impact of Covid-19 Pandemic on Primary Sector: The impact on this sector is likely to be low on both primary agricultural production and usage of agricultural inputs- like fertilizers and pesticides. Early sowing of the summer rice crop has covered 375 more area than the same time the previous year, despite of the lockdown limitations. (Agricultural Ministry Data) overall sowing of summer crops including rice, coarse cereals, oil seeds, is about $31 \%$ higher than the usual. In total 48.8 lakh hectares of land have been sown so far. The centre exempted agricultural activities from lockdown. Restrictions and has taken steps to ensure the availability of fertilizers and pesticides for the coming season ${ }^{39}$.

\subsubsection{Impact of Covid-19 Pandemic on Secondary Sector:}

In the manufacturing sector, the lockdown strategy adopted to deal with the pandemic had great impact on production and employment, it declined during the period It will take time for the manufacturing sector to ramp up with some of the loses in production given health precautions including social distancing. The demand for the capital goods, automobiles and trucks also showed decline, but after relaxation was given in lockdown conditions in some states, the demand being initially soft.At this moment, without appropriate support more than 6.3 crore MSMEs Micro small and medium enterprises stand on the very of economic rain. Every single day of the lockdown come at a cost of Rs30000cr. To this sector,dealing with ale orders and complete cessation of work.

3.1.1.1.1 Impact of covid-19 Pandemic on Tertiary sector: Finance and real-estate and professional services was estimated to be the hardest hit by the covid-19pandemic in India between April and June 2020, compared to the same period in $2019^{40}$. The transition of COVID-19 has a very bad impact on tourism, horticulture and self-employment.

3.1.1.1.1.1. Impact on Demand/Supply: according to don and brad street, besides the impact on human lives and global supply chains the pandemic is a severe demand shock, which has off set the green shoots of recovery of the Indian economy, that were visible towards the end of 2019 and early $2020^{41}$.

4. Impact of Covid-19 on Global Economy: The covid-19 pandemic is inflicting high and rising human costs worldwide, and the necessary protection measures are severely impacting economic activity. As a result of the pandemic, the global economy is projected to contract sharply by-3\% in 2020, much worse than during the 2008-09 financial crises ${ }^{42}$.For the first time since the great depression, both advanced economies and emerging market and developing economies are is recession. For this year, growth on advanced economies is projected at-6.1\% emerging market and developing economies with normal growth levels well above advanced are also projected to have negative growth rates of $-1.0 \%$ in 2020 , and2.25 if you exclude china ${ }^{43}$. The covid-19 pandemic has adversely effected the global economic growth. Estimates indicate 
that the virus could trim the global economic growth by as much as $2 \%$ per month if current condition persists. The global trade could also fall by $13 \%$ to $32 \%$ depending upon the global economic lockdown ${ }^{44}$.The analysis by the UN department of Economic and Social Affairs said that covid-19 pandemic is disrupting global supply chains and international trade. With nearly 100 countries closing national borders during the past month, the movement of people and tourism flows has come to a screeching halt.Millions of workers in these countries are facing problems of losing jobs, covid-19 could plunge the global economy into deep recession ${ }^{45}$.

\section{DATA ANALYSIS}

There are daily release reports submitted by WHO for corona virus infection data. WHO published its first report on $21^{\text {st }}$ January 2020, which included data dated on January 20, 2020. A total of 282 were infected in a total of 4 countries, including China, while the total number of infected in china alone was 278 and 6 persons died. After 13 weeks of the world, corona infections spread to a total of 212 countries and territories, with a total number of infected person reaching 2314621 and the total deaths reached 157847 on January 20, 2020“Table 1”.

Table 1: The Data of Total Confirmed Cases and Total Deaths Cases with Percentage in the World

\begin{tabular}{|c|c|c|c|c|c|c|c|}
\hline $\begin{array}{l}\text { S. } \\
\text { No }\end{array}$ & \multicolumn{2}{|c|}{$\begin{array}{l}\text { No. of Week with } \\
\text { Period(Date to date) }\end{array}$} & $\begin{array}{c}\text { TotalConfirmed } \\
\text { Cases } \\
\end{array}$ & TotalDeaths & $\begin{array}{c}\text { Total no. of } \\
\text { Countries }\end{array}$ & $\begin{array}{c}\text { TotalConfirmed } \\
\text { Cases in } \%\end{array}$ & $\begin{array}{c}\text { TotalDeaths } \\
\%\end{array}$ \\
\hline 1 & $\begin{array}{l}\text { No of } \\
\text { Week }\end{array}$ & Till on 20 Jan & 282 & 6 & 4 & 0 & 0 \\
\hline 2 & I & 21 Jan - 27Jan & 2798 & 80 & 12 & 892 & 1233 \\
\hline 3 & II & $\begin{array}{l}28 \text { Jan }-03 \\
\text { Feb }\end{array}$ & 17391 & 362 & 24 & 522 & 353 \\
\hline 4 & III & $\begin{array}{l}04 \mathrm{Feb}-10 \\
\text { Feb }\end{array}$ & 40554 & 910 & 25 & 133 & 151 \\
\hline 5 & IV & $\begin{array}{l}11 \mathrm{Feb}-17 \\
\text { Feb }\end{array}$ & 71429 & 1775 & 25 & 76 & 95 \\
\hline 6 & V & $\begin{array}{l}18 \text { Feb }-24 \\
\text { Feb }\end{array}$ & 79331 & 2618 & 29 & 11 & 47 \\
\hline 7 & VI & $\begin{array}{l}25 \mathrm{Feb}-02 \\
\text { Mar }\end{array}$ & 88948 & 3043 & 64 & 12 & 16 \\
\hline 8 & VII & $\begin{array}{l}\text { 03 Mar - } 09 \\
\text { Mar }\end{array}$ & 109577 & 3809 & 105 & 23 & 25 \\
\hline 9 & VIII & $\begin{array}{l}\text { 10 Mar - } 16 \\
\text { Mar }\end{array}$ & 167515 & 6606 & 151 & 53 & 73 \\
\hline 10 & IX & $\begin{array}{l}17 \text { Mar - } 23 \\
\text { Mar }\end{array}$ & 332930 & 14509 & 190 & 99 & 120 \\
\hline 11 & $X$ & $\begin{array}{l}24 \text { Mar - } 30 \\
\text { Mar }\end{array}$ & 693282 & 33106 & 203 & 108 & 128 \\
\hline 12 & XI & $\begin{array}{l}31 \mathrm{Mar}-06 \\
\text { Apr }\end{array}$ & 1210956 & 67594 & 209 & 75 & 104 \\
\hline 13 & XII & $\begin{array}{l}\text { 07 Apr - } 13 \\
\text { Apr }\end{array}$ & 1773084 & 111652 & 212 & 46 & 65 \\
\hline 14 & XIII & $\begin{array}{l}14 \text { Apr - } 20 \\
\text { Apr }\end{array}$ & 2314621 & 157847 & 212 & 31 & 41 \\
\hline
\end{tabular}

The impact of corona virus spread to 12 countries in the first week (January 21 to January 27) and the number of infected persons increased by $892 \%$ and the number of dead persons by $1233 \%$, but was only less based on the number in the world. The growth rate of infected persons was $11 \%$ lowest in the fifth week as compared to the previous week and the number of persons dying was the $16 \%$ lowest in the sixth week. 


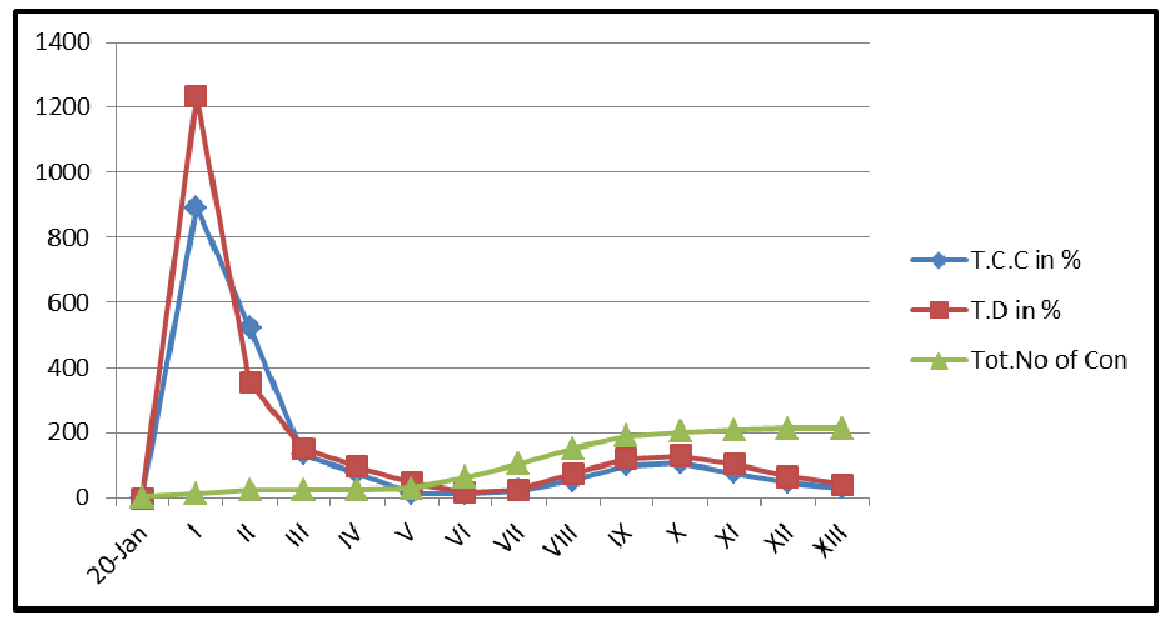

Figure 1: Curve of Total Numbers of Confirmed Cases, Deaths Cases and their Percentage in World.

The study of the data shows that the number of infected and deaths increased abruptly from the eighth week in the world.In the tenth week in the world, the number of infected persons compared to the ninth week was 360392 (108\%) and the number of persons dead was 18597 (128\%) registered an increase. In the next three weeks after the tenth week, the number of infected persons increased by $75 \%, 46 \%$ and $31 \%$ respectively, and the number deceased by $104 \%$, $65 \%$, and $41 \%$, respectively.Compared with data from the U.S.A, Spain, Italy, Germany, France, China and the United Kingdom, the most affected countries of Coronavirus infection were compared to 4 countries including China only on January 20, 2020, five cases were reported in the U.S.A, 3 in France, from the first week ( $21^{\text {st }}$ to $27^{\text {th }}$ January).

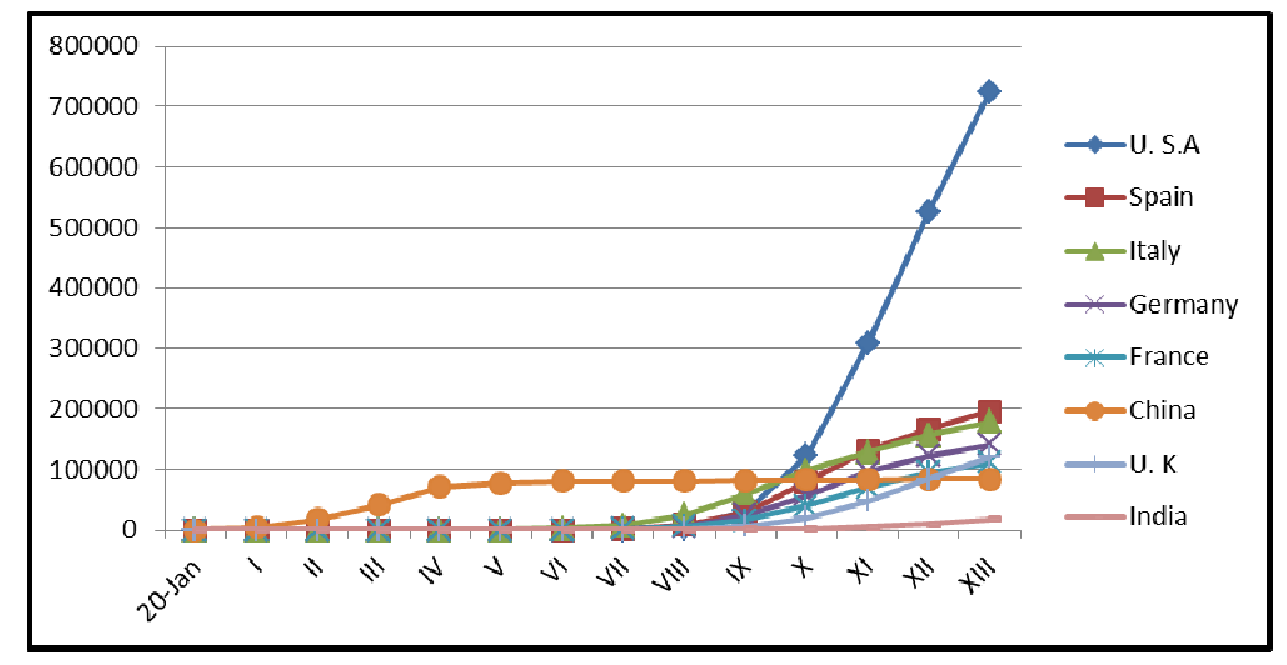

Figure 2: Curve of Total Numbers of Confirmed Cases in seven Highest Countries and India

Table 2: The data of Total Confirmed cases and Total Deaths case in Seven Highest Countries and India

\begin{tabular}{|c|c|c|c|c|c|c|c|c|c|c|c|c|c|c|c|c|c|c|}
\hline \multirow{3}{*}{$\begin{array}{l}\text { S. } \\
\mathbf{N} \\
\text { o }\end{array}$} & \multirow{3}{*}{\multicolumn{2}{|c|}{$\begin{array}{c}\text { No. of } \\
\text { Week } \\
\text { with } \\
\text { Period } \\
\text { Date to } \\
\text { date }\end{array}$}} & \multicolumn{16}{|c|}{ Reporting Countries } \\
\hline & & & \multicolumn{2}{|c|}{ U.S.A } & \multicolumn{2}{|c|}{ Spain } & \multicolumn{2}{|c|}{ Italy } & \multicolumn{2}{|c|}{ Germany } & \multicolumn{2}{|c|}{ France } & \multicolumn{2}{|c|}{ China } & \multicolumn{2}{|c|}{ U. K } & \multicolumn{2}{|c|}{ India } \\
\hline & & & T.C. & T.D & $\underset{\text { C }}{\text { T.C. }}$ & T.D & $\underset{\text { C }}{\text { T.C. }}$ & T.D & $\underset{\text { C }}{\text { T.C. }}$ & $\begin{array}{l}\text { T. } \\
\text { D }\end{array}$ & $\begin{array}{r}\text { T.C. } \\
\text { C }\end{array}$ & T.D & $\underset{\text { C }}{\text { T.C. }}$ & $\begin{array}{l}\text { T. } \\
\text { D }\end{array}$ & T.C & T.D & $\begin{array}{c}\text { T.C. } \\
\text { C }\end{array}$ & $\begin{array}{l}\text { T. } \\
\text { D }\end{array}$ \\
\hline 1 & $\begin{array}{c}\begin{array}{c}\text { No. } \\
\text { of } \\
\text { We } \\
\text { ek }\end{array}\end{array}$ & $\begin{array}{l}\text { Til } \\
1 \\
\text { on } \\
20 \\
\text { Ja } \\
\mathrm{n}\end{array}$ & 0 & 0 & 0 & 0 & 0 & 0 & 0 & 0 & 0 & 0 & 278 & 6 & 0 & 0 & 0 & 0 \\
\hline
\end{tabular}




\begin{tabular}{|c|c|c|c|c|c|c|c|c|c|c|c|c|c|c|c|c|c|c|}
\hline 2 & I & $\begin{array}{l}21 \\
\mathrm{Ja} \\
\mathrm{n}- \\
27 \\
\mathrm{Ja} \\
\mathrm{n}\end{array}$ & 5 & 0 & 0 & 0 & 0 & 0 & 0 & 0 & 3 & 0 & $\begin{array}{c}276 \\
1\end{array}$ & 80 & 0 & 0 & 0 & 0 \\
\hline 3 & II & $\begin{array}{l}28 \\
\mathrm{Ja} \\
\mathrm{n}- \\
03 \\
\mathrm{Fe} \\
\mathrm{b} \\
\end{array}$ & 11 & 0 & 1 & 0 & 2 & 0 & 10 & 0 & 6 & 0 & $\begin{array}{c}172 \\
38\end{array}$ & 361 & 2 & 0 & 3 & 0 \\
\hline 4 & III & $\begin{array}{l}04 \\
\mathrm{Fe} \\
\mathrm{b}- \\
10 \\
\mathrm{Fe} \\
\mathrm{b}\end{array}$ & 12 & 0 & 2 & 0 & 3 & 0 & 14 & 0 & 11 & 0 & $\begin{array}{c}402 \\
35\end{array}$ & 909 & 4 & 0 & 3 & 0 \\
\hline 5 & IV & $\begin{array}{l}11 \\
\mathrm{Fe} \\
\mathrm{b}- \\
17 \\
\mathrm{Fe} \\
\mathrm{b}\end{array}$ & 15 & 0 & 2 & 0 & 3 & 0 & 16 & 0 & 12 & 1 & $\begin{array}{c}706 \\
35\end{array}$ & $\begin{array}{c}177 \\
2\end{array}$ & 9 & 0 & 3 & 0 \\
\hline 6 & V & $\begin{array}{l}18 \\
\mathrm{Fe} \\
\mathrm{b}- \\
24 \\
\mathrm{Fe} \\
\mathrm{b} \\
\end{array}$ & 35 & 0 & 2 & 0 & 124 & 2 & 16 & 0 & 12 & 1 & $\begin{array}{c}772 \\
62\end{array}$ & $\begin{array}{c}259 \\
5\end{array}$ & 9 & 0 & 3 & 0 \\
\hline 7 & VI & $\begin{array}{l}25 \\
\mathrm{Fe} \\
\mathrm{b}- \\
02 \\
\mathrm{M} \\
\mathrm{ar}\end{array}$ & 62 & 2 & 45 & 1 & 1689 & 35 & 129 & 0 & 100 & 2 & $\begin{array}{l}801 \\
74\end{array}$ & $\begin{array}{l}291 \\
5\end{array}$ & 36 & 0 & 3 & 0 \\
\hline 8 & VII & $\begin{array}{l}03 \\
\text { M } \\
\text { ar } \\
- \\
09 \\
\text { M } \\
\text { ar }\end{array}$ & 213 & 11 & 589 & 10 & 7375 & 366 & 1112 & 0 & 1116 & 19 & $\begin{array}{l}809 \\
04\end{array}$ & $\begin{array}{l}312 \\
3\end{array}$ & 277 & 2 & 43 & 0 \\
\hline 9 & $\begin{array}{l}\text { VII } \\
\text { I }\end{array}$ & $\begin{array}{l}10 \\
\mathrm{M} \\
\mathrm{ar} \\
- \\
16 \\
\mathrm{M} \\
\mathrm{ar}\end{array}$ & 1678 & 41 & 7753 & 288 & $\begin{array}{l}2474 \\
7\end{array}$ & $\begin{array}{l}180 \\
9\end{array}$ & 4838 & 12 & 5380 & 127 & $\begin{array}{l}810 \\
77\end{array}$ & $\begin{array}{l}321 \\
8\end{array}$ & 1395 & 35 & 114 & 2 \\
\hline $\begin{array}{l}1 \\
0\end{array}$ & IX & $\begin{array}{l}17 \\
\mathrm{M} \\
\mathrm{ar} \\
- \\
23 \\
\mathrm{M} \\
\mathrm{ar}\end{array}$ & $\begin{array}{l}3157 \\
3\end{array}$ & 402 & $\begin{array}{l}2857 \\
2\end{array}$ & $\begin{array}{l}172 \\
0\end{array}$ & $\begin{array}{l}5913 \\
8\end{array}$ & $\begin{array}{l}547 \\
6\end{array}$ & $\begin{array}{l}2477 \\
4\end{array}$ & 94 & $\begin{array}{l}1582 \\
1\end{array}$ & 674 & $\begin{array}{l}816 \\
01\end{array}$ & $\begin{array}{l}327 \\
6\end{array}$ & 5687 & 281 & 415 & 7 \\
\hline $\begin{array}{l}1 \\
1\end{array}$ & $\mathbf{X}$ & $\begin{array}{l}24 \\
\text { M } \\
\text { ar } \\
- \\
30 \\
\text { M } \\
\text { ar }\end{array}$ & $\begin{array}{l}1226 \\
53\end{array}$ & $\begin{array}{l}211 \\
2\end{array}$ & $\begin{array}{l}7879 \\
7\end{array}$ & $\begin{array}{l}652 \\
8\end{array}$ & $\begin{array}{l}9768 \\
9\end{array}$ & $\begin{array}{l}107 \\
81\end{array}$ & $\begin{array}{l}5729 \\
8\end{array}$ & 455 & $\begin{array}{l}3964 \\
2\end{array}$ & $\begin{array}{l}260 \\
2\end{array}$ & $\begin{array}{l}824 \\
47\end{array}$ & $\begin{array}{l}331 \\
0\end{array}$ & $\begin{array}{l}1952 \\
6\end{array}$ & $\begin{array}{l}122 \\
8\end{array}$ & $\begin{array}{l}107 \\
1\end{array}$ & 9 \\
\hline $\begin{array}{l}1 \\
2\end{array}$ & XI & $\begin{array}{l}31 \\
\mathrm{M} \\
\mathrm{ar} \\
- \\
06 \\
\mathrm{Ap} \\
\mathrm{r}\end{array}$ & $\begin{array}{l}3073 \\
18\end{array}$ & $\begin{array}{l}835 \\
8\end{array}$ & $\begin{array}{l}1307 \\
59\end{array}$ & $\begin{array}{l}124 \\
18\end{array}$ & $\begin{array}{l}1289 \\
48\end{array}$ & $\begin{array}{l}158 \\
89\end{array}$ & $\begin{array}{l}9539 \\
1\end{array}$ & $\begin{array}{l}143 \\
4\end{array}$ & $\begin{array}{l}6960 \\
7\end{array}$ & $\begin{array}{l}806 \\
4\end{array}$ & $\begin{array}{l}830 \\
05\end{array}$ & $\begin{array}{l}334 \\
0\end{array}$ & $\begin{array}{l}4781 \\
0\end{array}$ & $\begin{array}{l}493 \\
4\end{array}$ & $\begin{array}{l}406 \\
7\end{array}$ & $\begin{array}{l}10 \\
9\end{array}$ \\
\hline
\end{tabular}




\begin{tabular}{|c|c|c|c|c|c|c|c|c|c|c|c|c|c|c|c|c|c|c|}
\hline $\begin{array}{l}1 \\
3\end{array}$ & XII & $\begin{array}{l}07 \\
\text { Ap } \\
r \text { - } \\
13 \\
\text { Ap } \\
\text { r }\end{array}$ & $\begin{array}{l}5245 \\
14\end{array}$ & $\begin{array}{l}204 \\
44\end{array}$ & $\begin{array}{l}1660 \\
19\end{array}$ & $\begin{array}{l}169 \\
72\end{array}$ & $\begin{array}{l}1563 \\
63\end{array}$ & $\begin{array}{l}199 \\
01\end{array}$ & $\begin{array}{l}1230 \\
16\end{array}$ & $\begin{array}{l}279 \\
9\end{array}$ & $\begin{array}{l}9438 \\
2\end{array}$ & $\begin{array}{l}143 \\
74\end{array}$ & $\begin{array}{l}835 \\
97\end{array}$ & $\begin{array}{l}335 \\
1\end{array}$ & $\begin{array}{l}8428 \\
3\end{array}$ & $\begin{array}{l}106 \\
12\end{array}$ & $\begin{array}{l}915 \\
2\end{array}$ & $\begin{array}{l}30 \\
8\end{array}$ \\
\hline $\begin{array}{l}1 \\
4\end{array}$ & $\begin{array}{l}\text { XII } \\
\text { I }\end{array}$ & $\begin{array}{l}14 \\
\text { Ap } \\
\mathrm{r}- \\
20 \\
\text { Ap } \\
\mathrm{r}\end{array}$ & $\begin{array}{l}7236 \\
05\end{array}$ & $\begin{array}{l}342 \\
03\end{array}$ & $\begin{array}{l}1959 \\
44\end{array}$ & $\begin{array}{l}204 \\
53\end{array}$ & $\begin{array}{l}1789 \\
72\end{array}$ & $\begin{array}{l}236 \\
60\end{array}$ & $\begin{array}{l}1416 \\
72\end{array}$ & $\begin{array}{l}440 \\
4\end{array}$ & $\begin{array}{l}1114 \\
63\end{array}$ & $\begin{array}{l}196 \\
89\end{array}$ & $\begin{array}{l}842 \\
37\end{array}$ & $\begin{array}{l}464 \\
2\end{array}$ & $\begin{array}{l}1200 \\
71\end{array}$ & $\begin{array}{l}160 \\
60\end{array}$ & $\begin{array}{l}172 \\
65\end{array}$ & $\begin{array}{l}54 \\
3\end{array}$ \\
\hline
\end{tabular}

Abbreviations: T.C.C $=$ Total confirmed cases, T.D = Total deaths, U.S.A= United States of America, U.K= United Kingdom In the second week, one in Spain, two in Italy, 10 in Germany, two in United Kingdom and 3 in India were reported. In china, the number of infected persons increased by $893 \%$ and the number of deaths by $1233 \%$ in the first week, which is highest based on the growth rate in the world. In the fifth week, Italy grew by $4033 \%$ compared to the fourth week who was highest growth compared to all seven countries. In the sixth week, the number of infected persons increased by $2150 \%, 1262 \%, 706 \%, 733 \%$ and 300\% respectively in Spain, Italy, Germany, France and United Kingdom, while the deaths toll in China this week was1915 and Italy 35 (Table 1, figure 2). The total number of infected persons in India, Spain and France increased by $1333 \%$ to $1209 \%$ and $1016 \%$ respectively, as compared to the sixth week in the seventh week. The death toll this week was $946 \%$ in Italy, Spain in $900 \%$, France in $850 \%$ and $450 \%$ USA. By the end of the eightweek, there was maximum increase in the number of Coronavirus patients in the all seven countries, including India.

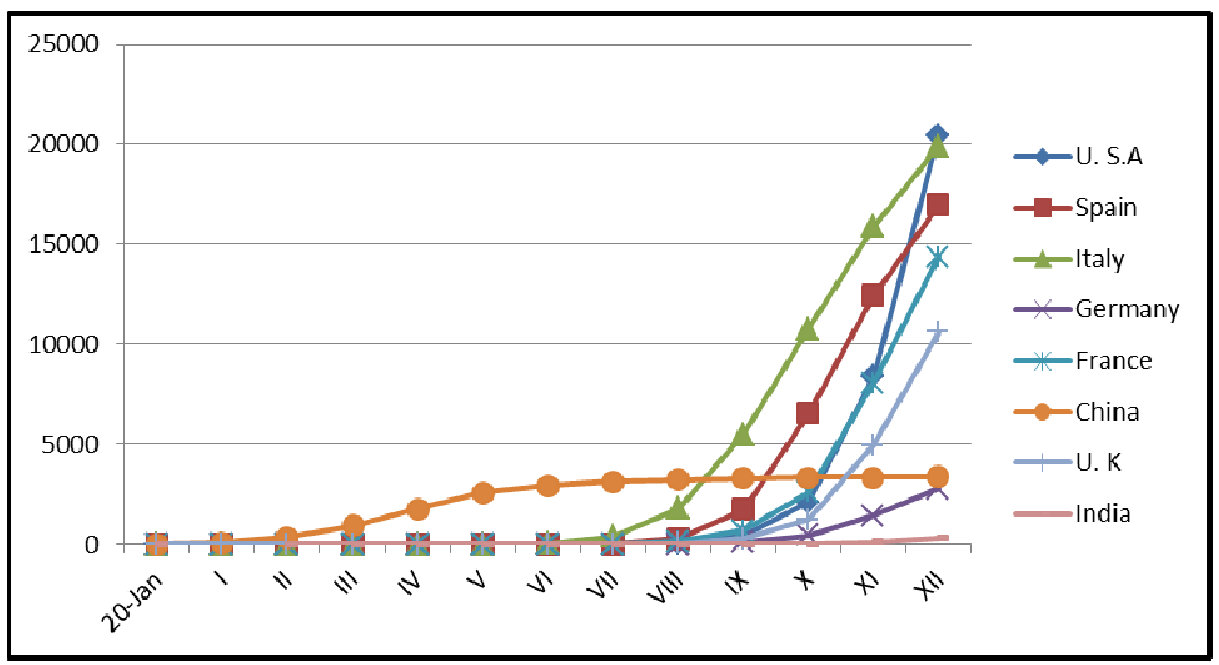

Figure 3: Curve of Total Numbers of Deaths Cases in Seven Highest Countries and India

The maximum increase in Spain as compared to the seventh week was1216\%, while the maximum of those who died was $2780 \%$ in Spain increased. The maximum increase in Spain increased by $1216 \%$ while the maximum in the dying person increased by $2780 \%$ in Spain and $1650 \%$ in United kingdom. The number of most infected persons in the ninth week as compared to the eighth week was 29895 (1782\%) in USA and the highest number of persons who died was 3667 (203\%) in Italy. Based on the data, the number of infected persons had gone up to 30400 in the third week in China, 38551 in the tenth week in Italy. Spain had grown to 51962, 38093, 29965 corona infected in the eleventh week in Germany and France respectively. The U.S.A and U.K recorded a maximum growth of 217196 and 36473 in $12^{\text {th }}$ weeks, respectively, while India recorded a total growth of 1113 in the thirteenth week. The death toll in these countries was 5305 in Italy in the tenth week, 5890 in Spain and 6310, or 5678 in the UK respectively, while the US, Germany was 13759, 1605,1291 and 235 in 
13 week, respectively. In China and India, a total of 3 patient remained in the second week till the $6^{\text {th }}$ week, while the number of patient increased steadily from the seventh week as the rate of testing in patients in India was very low for 6 weeks, so the rate of infection in India was low. The rate of corona virus infection in India was recorded very low as compared to the most affected countries, which can be considered very well for India "Table 2", "Table 3", "figure 1", "figure 2" "figure 3".

Table 3: The percentage of Total Confirmed Cases and Total Deaths Case in Seven Highest Countries and India

\begin{tabular}{|c|c|c|c|c|c|c|c|c|c|c|c|c|c|c|c|c|c|c|}
\hline \multirow{3}{*}{$\begin{array}{l}\mathbf{S} \\
\dot{\mathbf{N}} \\
\mathbf{0}\end{array}$} & \multirow{3}{*}{\multicolumn{2}{|c|}{$\begin{array}{c}\text { No. of } \\
\text { Week with } \\
\text { Period } \\
\text { Date to } \\
\text { date }\end{array}$}} & \multicolumn{16}{|c|}{ Reporting Country } \\
\hline & & & \multicolumn{2}{|c|}{ U.S.A } & \multicolumn{2}{|c|}{ Spain } & \multicolumn{2}{|c|}{ Italy } & \multicolumn{2}{|c|}{ Germany } & \multicolumn{2}{|c|}{ France } & \multicolumn{2}{|c|}{ China } & \multicolumn{2}{|c|}{ U. K } & \multicolumn{2}{|c|}{ India } \\
\hline & & & $\begin{array}{c}\text { T.C. } \\
\text { C } \\
(\%)\end{array}$ & $\begin{array}{c}\mathrm{T} . \\
\mathbf{D} \\
(\%\end{array}$ & $\begin{array}{c}\text { T.C.C } \\
(\%)\end{array}$ & $\begin{array}{c}\text { T. } \\
\mathbf{D} \\
(\%\end{array}$ & $\begin{array}{c}\text { T.C } \\
\text {.C } \\
(\%)\end{array}$ & $\begin{array}{l}\text { T.D } \\
(\%)\end{array}$ & $\begin{array}{c}\text { T.C. } \\
\text { C } \\
(\%)\end{array}$ & $\begin{array}{c}\text { T. } \\
\mathbf{D} \\
(\%\end{array}$ & $\begin{array}{c}\text { T.C. } \\
\text { C } \\
(\%)\end{array}$ & $\begin{array}{c}\text { T. } \\
\mathbf{D} \\
(\%\end{array}$ & $\begin{array}{c}\text { T.C. } \\
\text { C } \\
(\%)\end{array}$ & $\begin{array}{l}\text { T.D } \\
(\%)\end{array}$ & $\begin{array}{c}\text { T.C. } \\
\text { C } \\
(\%)\end{array}$ & $\begin{array}{l}\text { T.D } \\
(\%)\end{array}$ & $\begin{array}{c}\text { T.C. } \\
\text { C } \\
(\%)\end{array}$ & $\begin{array}{c}\text { T. } \\
\text { D } \\
\text { ( }\end{array}$ \\
\hline 1 & $\begin{array}{l}\text { No. } \\
\text { of } \\
\text { We } \\
\text { ek }\end{array}$ & $\begin{array}{l}\text { Till } \\
\text { on } \\
20 \\
\text { Jan }\end{array}$ & 0 & 0 & 0 & 0 & 0 & 0 & 0 & 0 & 0 & 0 & 278 & 0 & 0 & 0 & 0 & 0 \\
\hline 2 & $\mathbf{I}$ & $\begin{array}{l}21 \\
\text { Jan - } \\
27 \mathrm{Ja} \\
\mathrm{n}\end{array}$ & 0 & 0 & 0 & 0 & 0 & 0 & 0 & 0 & 0 & 0 & 893 & $\begin{array}{c}123 \\
3\end{array}$ & 0 & 0 & 0 & 0 \\
\hline 3 & II & $\begin{array}{l}28 \\
\text { Jan - } \\
03 \\
\text { Feb }\end{array}$ & 120 & 0 & 0 & 0 & 0 & 0 & 0 & 0 & 100 & 0 & 524 & 351 & 0 & 0 & 0 & 0 \\
\hline 4 & III & $\begin{array}{l}04 \\
\text { Feb - } \\
10 \\
\text { Feb }\end{array}$ & 9 & 0 & 100 & 0 & 50 & 0 & 40 & 0 & 83 & 0 & 133 & 152 & 100 & 0 & 0 & 0 \\
\hline 5 & IV & $\begin{array}{l}11 \\
\text { Feb - } \\
17 \\
\text { Feb }\end{array}$ & 25 & 0 & 0 & 0 & 0 & 0 & 14 & 0 & 9 & 0 & 76 & 95 & 125 & 0 & 0 & 0 \\
\hline 6 & $\mathbf{V}$ & $\begin{array}{l}18 \\
\text { Feb - } \\
24 \\
\text { Feb }\end{array}$ & 133 & 0 & 0 & 0 & $\begin{array}{l}403 \\
3\end{array}$ & 0 & 0 & 0 & 0 & 0 & 9 & 46 & 0 & 0 & 0 & 0 \\
\hline 7 & VI & $\begin{array}{l}25 \\
\text { Feb - } \\
02 \\
\text { Mar }\end{array}$ & 77 & 0 & 2150 & 0 & $\begin{array}{l}126 \\
2\end{array}$ & $\begin{array}{l}165 \\
0\end{array}$ & 706 & 0 & 733 & $\begin{array}{l}10 \\
0\end{array}$ & 4 & 12 & 300 & 0 & 0 & 0 \\
\hline 8 & VII & $\begin{array}{l}03 \\
\text { Mar } \\
-\quad 09 \\
\text { Mar }\end{array}$ & 244 & $\begin{array}{l}45 \\
0\end{array}$ & 1209 & $\begin{array}{l}90 \\
0\end{array}$ & 337 & 946 & 762 & 0 & 1016 & $\begin{array}{l}85 \\
0\end{array}$ & 1 & 7 & 669 & 0 & 1333 & 0 \\
\hline 9 & $\begin{array}{l}\text { VII } \\
\text { I }\end{array}$ & $\begin{array}{l}10 \\
\text { Mar } \\
-16 \\
\text { Mar }\end{array}$ & 688 & $\begin{array}{l}27 \\
3\end{array}$ & 1216 & $\begin{array}{l}27 \\
80\end{array}$ & 236 & 394 & 335 & 0 & 382 & $\begin{array}{l}56 \\
8\end{array}$ & 0 & 3 & 404 & $\begin{array}{l}165 \\
0\end{array}$ & 165 & 2 \\
\hline $\begin{array}{l}1 \\
0\end{array}$ & IX & $\begin{array}{l}17 \\
\text { Mar } \\
-23 \\
\text { Mar }\end{array}$ & 1782 & $\begin{array}{l}88 \\
0\end{array}$ & 269 & $\begin{array}{l}49 \\
7\end{array}$ & 139 & 203 & 412 & $\begin{array}{l}68 \\
3\end{array}$ & 194 & $\begin{array}{l}43 \\
1\end{array}$ & 1 & 2 & 308 & 703 & 264 & $\begin{array}{l}25 \\
0\end{array}$ \\
\hline $\begin{array}{l}\mathbf{1} \\
\mathbf{1}\end{array}$ & $\mathbf{X}$ & $\begin{array}{l}24 \\
\text { Mar } \\
-\quad 30 \\
\text { Mar }\end{array}$ & 288 & $\begin{array}{l}42 \\
5\end{array}$ & 176 & $\begin{array}{l}28 \\
0\end{array}$ & 65 & 97 & 131 & $\begin{array}{l}38 \\
4\end{array}$ & 151 & $\begin{array}{l}28 \\
6\end{array}$ & 1 & 1 & 243 & 337 & 158 & 29 \\
\hline $\begin{array}{l}1 \\
2\end{array}$ & XI & $\begin{array}{l}31 \\
\text { Mar } \\
-\quad 06 \\
\text { Apr }\end{array}$ & 151 & $\begin{array}{l}29 \\
6\end{array}$ & 66 & 90 & 32 & 47 & 66 & $\begin{array}{l}21 \\
5\end{array}$ & 76 & $\begin{array}{l}21 \\
0\end{array}$ & 1 & 1 & 145 & 302 & 280 & $\begin{array}{l}11 \\
11\end{array}$ \\
\hline $\begin{array}{l}1 \\
3\end{array}$ & XII & $\begin{array}{l}07 \\
\text { Apr } \\
-\quad 13 \\
\text { Apr }\end{array}$ & 71 & $\begin{array}{l}14 \\
5\end{array}$ & 27 & 37 & 21 & 25 & 29 & 95 & 36 & 78 & 1 & 0 & 76 & 115 & 125 & $\begin{array}{l}18 \\
3\end{array}$ \\
\hline
\end{tabular}




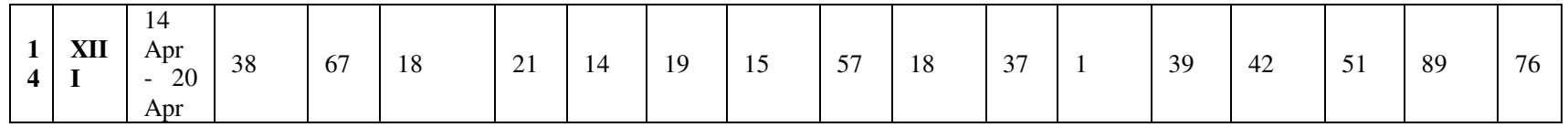

Abbreviations: T.C.C $=$ Total confirmed cases, T.D= Total deaths, U.S.A= United States of America, U.K= United Kingdom

\section{DISCUSSIONS AND CONCLUSIONS}

Life and livelihood of 26.9 crore or 21 percent of country's people live below the poverty line. There are only 219 facilities in 720 districts of the country till $16^{\text {th }}$ April, after knocking in Kerala of covid-19 on $30^{\text {th }}$ January. The rate of investigation in India was 196 out of the very low per 10 lakh people on $16^{\text {th }}$ April. We need an investigation of 1.39 crore people to reach South Korea's investigation level (10,550 per million). We need to examine 60 lakh people to match 4750 per 10 lakh in Britain. Till $16^{\text {th }}$ April, only 258730 people were screened. There is also no corrosion against viruses.About 55 medicines of covid-19 had reached different staged of development and testing. So, on March 20, WHO allowed drug testing in 15 countries including India.The final treatment of accelerating the development of medicines is vaccine. The malaria drug Hydroxychloroquine for covid-19 is also being used on an increased scale. There is a vaccine of 15 such diseases. According to WHO's list, 44 vaccines are being created together in the world.In India, the number of 516 patients and 9 deaths was limited on the day of the announcement of the first lathe for 21 days on March 24, which had killed 11487 patients and 393 till April 14. The Ministry of Health and family Welfare, Government of India, believes that there has been a good help in reducing the pace of epidemics in the Lockdown. India took 6 days to reach 12000 patients from 6000 patients while the US took 2 days, Italy 3 days and Spain 4 days. The Indian economy is losing Rs 2 lack crore per week from this down in a report by the State Bank of India, which could increase the GDP to 1\% in the financial year 2020-21, reducing the income of 37.3 crore workers.On March 25, the government of India announced a total of Rs 1.7 million crore, which is being provided for cylinder ration for the poor. India has made a provision 15000 crore in emergency plan item. In India, relief and rescue operations are being carried out in three parts of the covid-19 affected areas, severe outbreak hotspots (123 districts), low infected hotspots (47 districts) and unaffected hotspots ( 207 districts) by formulating a strategy for health services and economic activities after the first lakh ${ }^{45}$. The global pandemic of corona virus is seen to have an adverse effect on human life in the lockdown. There is a lot of change in the improvement in environment, rivers and air quality. While the ban on human and transport activities has made the water of rivers very clear, the non-functioning of vehicles and factories has reduced the quantity of $\mathrm{CO}_{2}, \mathrm{NO}_{2}$ and other gases in the air, which has greatly improved the air quality. At present, wild animals are being seen in the cities, which that this environmentallyrelated seems to be good. Scientists believe that, in areas where air pollution is high in large quantities, the infection of the corona virus is more than usual.

\section{REFERNCES}

1. N. M. Ferguson et al., "Impact of non-pharmaceutical interventions (npis) to reduce covid-19 mortality andhealthcare demand," London: Imperial College COVID-19 Response Team, 16 March 2020.

2. "Virus Taxonomy: 2018b Release," International Committee on Taxonomy of Viruses (ICTV). March 2019, Archived from the original on March 2018, Retrieved January 2020.

3. "Coronavirus disease 2019 (COVID-19)-Symptoms and causes" Mayo Clinic, Retrieved 14 April 2020.

4. Hui, D.S., Azhar, I., Madani T.A. E., Ntoumi, F., Kock. R., Dar, O., et al., "The continuing 2019- nCoV epidemic threat of 
novel Coronaviruses to global health-The latest 2019 novel coronavirus outbreak in Wuhan, China," Int J Infect Dis.,91, 26466, February 2020.

5. "WHO Director-General's opening remarks at the media briefing on COVID-19," World Health Organization(WHO) (Press release), 11 March 2020. Archived from the original on11 March 2020, Retrieved 12 March 2020.

6. "WHO Director-General's opening remarks at the media briefing on COVID-19," World Health Organization (WHO) (Press release), 11 March2020. Archived from the original on 11 March 2020, Retrieved 6 April2020.

7. "WHO Situation Report -65," 25 March 2020.

8. "Home Ministry of Health and Family Welfare GO," 5 March 2020.

9. "Statement on the second meeting of the International Health Regulations (2005) Emergency Committee regarding the outbreak of novel coronavirus (2019-nCoV), "World Health Organization (WHO), Archived fromthe original on 31 January 2020. Retrieved 11 February 2020.

10. Mahtani, S., Berger, M., O'Grady, S., Iati M, "Hundreds of evacuees to be held on bases in California; Hong Kong and Taiwan restrict travel from mainland China", The Washington Post. Archived from the originalon 7 February 2020. Retrieved 11 February 2020.

11. De Groot, R.J., Baker,S.C, Baric, R., Enjuanes, L., Gorbalenya, A.E., Holmes, K.V., Perlman, S., Poon, L., Rottier P.J, Talbot P.J, Woo PC, Ziebuhr J "Family Coronaviridae". In King AM, Lefkowitz E, Adams MJ, Carstens, E.B., "International Committee on Taxonomy of Viruses, International Union of Microbiological Societies, Virology Division (eds.). Ninth Report of the International Committee on Taxonomy of Viruses. OxfordElsevier.,2011 pp. 806-28.

12. International Committee on Taxonomy of Viruses"ICTV Master Species List 2009-V10," 2010.

13. Estola, T. "Coronaviruses, a New Group of Animal RNA Viruses," Avian Diseases.14(2): (1970) pp330-336.

14. Kahn, J.S., McIntosh. K., "History and recent advances in coronavirus discovery," The Pediatric Infectious Disease Journal, 24 November 2005, S223-27.

15. Geller, C., Varbanov, M., Duval, R.E. "Human coronaviruses: insights intoenvironmental resistance and its influence on the development of new antiseptic strategies" Viruses. November 2012.4 (11): pp 3044-68.

16. Definition of Coronavirus by Merriam-Webster, Merriam-Webster, archived from the original on 23 March 2020. retrieved24 March 2020.

17. Goldsmith, C. S., Tatti, K. M., Ksiazek, T. G., Rollin, P. E., Comer, J. A., Lee, W. W., et al, "Ultra structural characterization of SARS coronavirus". Emerging Infectious Diseases, February 2004,10(2), 320-26.

18. Woo, Patrick C. Y, Huang, Yi, Lau, Susanna K. P, Yuen, Kwok-Yung "Coronavirus Genomics and Bioinformatics Analysis" Viruses., 20102 (8), 1804-1820.

19. Shriyan, A. M. R. I. T. A., and A. S. H. V. I. J. Shriyan. "A study on the efficiency of CSSD at a health care center." TJPRC: Journal of Nursing and Patient Safety \& Care (TJPRC: JNPSC), 1 (2) (2015): 7-16.

20. Neuman, B.W., Adair, B.D., Yoshioka, C.,Quispe, J.D., Orca, G., Kuhn, P., et al. (). "Supramolecular architecture of severe acute respiratory syndrome coronavirus revealed by electron cryomicroscopy," Journal of Virology.,August 2006.80(16), pp7918-28.

21. Fehr, A.R., Perlman, S., Maier, H. J., Bickerton, E., Britton, P., (eds.) "Coronaviruses: an overview of their replication and pathogenesis," Methods in Molecular Biology., Springer, 2015,1282, 1-23. 
22. Murray and Nadel "Textbook of respiratory medicine" Chapter 31, 2010.

23. Almeida, J. D., Berry, D. M., Cunningham, C. H., Hamre, D., Hofstad, M. S., Mallucci, L., McIntosh, K., Tyrrell, D. A, "Virology: Coronaviruses, "Nature, November1968.220(5168): 650.

24. "Q\&A on coronaviruses," World Health Organization, 8 April 2020. Archived from the original on 20 January 2020., Retrieved 12 April 2020.

25. "How COVID-19 Spreads," Centers for Disease Control and Prevention (CDC), 2 April 2020. Archived from the original on 3 April 2020., Retrieved 3 April 2020.

26. "Modes of transmission of virus causing COVID-19: implications for IPC precaution recommendations," World Health Organization, 29 March 2020.Retrieved 3 April 2020.

27. "New coronavirus stable for hours on surfaces," National Institutes of Health, 17 March 2020.Archived from the original on 23 March 2020., Retrieved 23 March 2020.

28. "Coronavirus disease 2019 (COVID-19) Situation Report-73," World Health Organization, 2 April 2020.Retrieved 3 April 2020.

29. "How to Protect Yourself \& Others," Centers for Disease Control and Prevention (CDC), 8 April 2020. Archived from the original on 26 February 2020.,Retrieved 9 April 2020.

30. RAMAKRISHNAN, RANJANI. "Antiviral properties of Cyanobacterium, Spirulina platensis-a review." Int. J. Med. Pharm. Sci 3 (2013): 1-10.

31. Al-Khafaji, N. S. "Molecular Study of Some Virulence Factors among Pseudomonsaaeruginosa Recovered from Burn infection, Iraq." International Journal of Medicine and Pharmaceutical Sciences 4.3 (2014): 71-80.

32. Salehi, Sana, Abedi, Aidin. Balakrishnan, Sudheer., Gholamrezanezhad, Ali., "Coronavirus Disease 2019 (COVID-19): A Systematic Review of Imaging Findings in 919 Patients". American Journal of Roentgenology, 14 March 2020, 1-7.

33. "ACR Recommendations for the use of Chest Radiography and Computed Tomography (CT) for Suspected COVID-19 Infection, "AmericanCollege of Radiology, 22 March 2020., Archived from the original on 28 March 2020.

34. "Interim Clinical Guidance for Management of Patients with Confirmed Coronavirus Disease (COVID-19)," Centers for Disease Control and Prevention, 3 April 2020.Archived from the original on 2 March 2020., Retrieved 14 April 2020.

35. MANORAMA KANURI, AFIFA JAHAN. "EFFECT OF NON-EXPOSURE TO SUNLIGHT ON VITAMIN D STATUS OF FREE LIVING POPULATION." International Journal of Agricultural Science and Research (IJASR) ISSN(P): 2250-0057; ISSN(E): 2321-0087 Vol. 6, Issue 1, Feb 2016, 299-304

36. "Q\&A on Coronaviruses (COVID-19): How long is the incubation period for COVID-19," World Health Organization (WHO), Archived from the original on 20 January 2020. Retrieved 26 February 2020.

37. Lauer, Stephen. A.,Grants, Kyra. H. Bi., Qifang, Jones. Forrest, K., Zheng, Qulu., Meredith, Hannah. R., Azman, Andrew. S., Reich, Nicholas. G., Lessler, Justin.,"The Incubation Period of Coronavirus Disease 2019 (COVID-19) From Publicly Reported Confirmed Cases: Estimation and Application," 10 March 2020., Retrieved 24 March 2020.

38. "The health risks"The Hindu, April 12, 2020.

39. SALILEW, GETACHEW ABIYE. "A MATHEMATICAL ANALYSIS FOR CONTROLLING THE SPREAD OF HIV/AIDS WITH INDUCED DEATH." TJPRC: International Journal of HIV Medicine \& Research (TJPRC: IJHMR) 1.1, Dec 2016, 1-14

40. “What is the impact corona virus on Indian Economy,”Josh, Shika Goyal, April 25, 2020. 
41. INSTA summary of Economic survey Report 2019-2020, ”volume 2./https;//www.insightson india.com/

42. “CII Says India growth may slip to 1.5\%in Financial Year 2021,” The Hindu, April24,2020.pg.13.

43. “We are in crucial point in agriculture, demand for inputs may see pick-up," The Hindu, April 12, 2020.

44. "Estimated economic impact from cOVID-19 on India's GVA April- June 2020 by sector." Published byMadhumithaJaganmohan, April 26,2020.

45. AL-HUSSAINE, SAMER RA, and AZHAR AL AL-THAHAB. "SOME IMMUNOLOGICAL PARAMETERS OF VIRAL PEDIATRIC PNEUMONIA." International Journal of Medicine and Pharmaceutical Sciences (IJMPS) 4. 6, Dec 2014, 29-36

46. “Covid-19 pandemic severe demand shock for Indian Economy: D\&B,” Economic times, April 2020.

47. “World economic outlook” Chepter-1 April 2020.

48. The great to lockdown worst Economic downturn since the great Depression," Gita Gopinath,

49. https:/blogs.imf.org >2020/04/14, April 14,2020.

50. “Global Economic Effects of covid-19,"updated, congressional research service https:/crsreports.Congress.Govt. April 24,2020 .

51. EM, Umoffia, et al. "Feeding Options and HIV Status of Babies Whose Mothers Were on Antiretroviral Therapy in University of Teaching Hospital, Uyo, Nigeria." International Journal of Medicine and Pharmaceutical Science (IJMPS) ISSN (P) (2016): 2250-0049.

52. "Global Economy, could shrink by almost $1 \%$ is 2020 due to covid-19 pandemic, United Nations" PTI/ undated, Economic Times. April 02, 2020.

53. India Today, Year: 34, part 24, April 23-29, 2020. pp 3,16,20-21,29. 

